\title{
A PROTRAIT PARTICIPATION IN DECISION MAKING AMONG ACCOUNTING LECTURES IN YOGYAKARTA
}

\author{
Sukirno \\ Faculty of Economics Yogyakarta State University \\ email: soekirno_uny@yahoo.co.id
}

\begin{abstract}
As a developing country, Indonesia has been facing problems regarding finding the ways how to improve her higher education quality. In this study, lecturer participative decision making (hereafter abbreviated, PDM)) is observed and analysed to be linked with lecturer satisfation, commitment, and performance.Mail survey was used to collect the data. Open-ended questionnaires were distributed to the accounting lectures at faculty of economics and business in Yogyakarta Special Region, Indonesia. A total of 61usable packets of questionnaires were obtained by dual rater approach. Data were analyzed by employing tabulation, anovaandregressionanalysis.It is found that lecturer participation will increase lecturer performance. Nevertheles, lecturer participation is beyond the track of getting lecturer satisfaction and lecturer commitment. Lecturer participation may be useful to boost lecturer commitment based on the single rating. In response jangling results, theoritical and empirical discussion are presented to provide useful academic and managerial recomendations.
\end{abstract}

Keywords: participative decision making, higher education, Indonesia

\section{POTRET PARTISIPASI DOSEN AKUNTANSI DALAM PENGAMBILAN KEPUTUSAN DI INDONESIA}

\begin{abstract}
Abstrak: Sebagai negara berkembang, Indonesia menghadapi persoalan erkait dengan peningkatan kualitas pendidikan tinggi. Penelitian ini bertujuan untuk mengamati, mendeskripsi dan menganalisis partisipasi dosen dalam pengambilan keputusan dan pengaruhnya terhadap kepuasan, komitmen, dan kinerja dosen. Survei menggunakan angket semi terbuka dengan menggunakan rater ganda dilakukan untuk mengumpulkan data penelitian. Sejumlah 61 dosen akuntansi dari berbagai fakultas ekonomika dan bisnis di Daerah Istimewa Yogyakarta berpartisipasi dalam penelitian ini. Data yang diperoleh dianalisis dengan menggunakan tabulasi, Anova test dan analisis Regresi. Hasil penelitian berbasis pada single rating menunjukkan partisipasi dosen dalam pengambilan keputusan berpengaruh terhadap kinerja dosen, namun demikian partisipasi dosen tidak terbukti berpengaruh terhadap kepuasan dan komitmen dosen. Kesimpulan yang berbeda atas hasil analisis dalam penelitian ini didiskusikan dan dipresentasikan agar dapat dibuat rekomendasi akademik dan managerial yang berguna.
\end{abstract}

\section{Kata Kunci: pengambilan keputusan partisipatif, perguruan tinggi, Indonesia}

\section{PROBLEM BACKGROUND}

Higher education has the main role in creating knowledgeable and skilled human resources supporting the country development.It is the engine that drives the economy and vaccinates it against the worst effects of globalization (Creech, 2000). Porter (2002) asserts that performance of higher education has a significant effect for the nation's competitiveness.

Since 1999, the implementation of the spirit of the reform era, education system in Indonesia is no longer becoming stagnant. The government in making endeavor to implement higher education reform has been facing serious resistance from various groups in the society (Sulistiyono, 2007). Waves of student demonstrations and rejections that have occurred were from not only by students but also by Indonesian experts on education. Some issues which have been raised during the demonstrations are justice and equality of education distribution and comercialization of education resulting from the effort to transform public university to become 
Badan Hukum Pendidikan (BHP/Education Legal Institution).

The rapid population growth and economic crisis of 1997 also add not only the burden of Indonesian economy but also the problem of education system.Compared to its neighboring countries, the total education expenditures in Indonesia is still relatively low, although economic and demographic differences among countries should also be considered (Wicaksono \& Friawan, 2008). The budget for education was only about 1.5 percent of GDP in 2000, while Malaysia had reached 4.5 percent, the Philippines 3.5 percent, and even Zimbabwe was about 11.6 percent (Sulistiyono, 2007).

With such heavy educational problems and economic burden, it is very hard for Indonesian government to give reasonable proportion of attention, budget and facilities for education. Nevertheless, several efforts have been conducted by the government to minimize unexpected impacts. Brodjonegoro (1997) stated that in managing education, Indonesia has been advocating several strategies; autonomy, accountability, accreditation, self evaluation, and continuous quality improvement. Besides, Indonesian government has improved educational budget allocation gradually from $12 \%$ for 2006 to $21 \%$ for 2009 . Even so, the allocation of the budget improvement especially for the higher education department is still low (Ikhsan and Asih, 2008). Further, Ikhsan and Asihasserted thatthe main constraints regarding of low competency in human resources is still hindering the efforts of improving quality of the higher education in Indonesia.

Considerable effortshave been conducted to improve teacher professionalism in many different countries. Improving teacher participation in decision making is primarily related to the issues of school life and learning process (Rice and Schneider, 1994). Nevertheless, the impact of participation has been studied in the industrial and business domains throughout the world but only recently is it evident in schools. Participation has not only been of great interest to business researchers but also researchers in education because they are interested to inves- tigate if teacher participation relates to individual or institutional performance (Lipman, 1997; Clinton and Hunton, 2001). Parnell and Crandall (2003) found that participation in decision makingcan increase job satisfaction and ultimately will improve employee performance. It is also found that participative decision making significantly influences employee commitment and managerial performance (Boglera and Somech, 2004).

Education performance is the compilation of varied resources. Among them, teacher becomes a key success to achieve educational missions and goals. Teacher performance stands out as an important concern that is increasingly emphasized in education system across the country (Rice, 2003). Therefore, lecturer performance in higher education becomes a prominent element in coloring university performance and has been an interesting and important issue in educational studies. Nevertheless, lecturer performance evaluation is more difficult compared to other professions' performance evaluations. It is caused by its output that cannot be easily measured in a valid, reliable and fair way (Podgursky and Springer, 2007). Thus, providing a guideline to evaluate lecturer's performance is useful for education management. To provide a more distinct explanation, the following sections describe theoretical reviews of lecturer participation.

During the past decade, PDM and its relationship to various organizational outcomes have become a great concern of researchers in human resource management (Rice and Schneider, 1994). PDM at the workplace is considered as the essential element of a democratic vision and a good society. Participation is a crucial determinant for creating an efficient decisionmaking process in organizations (Zhong-Ming, 1994). PDM offers the possibility of resolving contradictory interests among different groups through individual negotiation (Alipour et al., 2009).

In some studies, employee participation (Aswathappa, 2002), are mentioned as job involvement (Rice and Schneider, 1994), employee empowerment (Marks and Louis, 1997), 
or PDM (Conway, 1980), all show the same objectives. Del-Val and Lloyd (2003) in general stated that empowerment, participation or participative management all are as synonyms as a classic concept in business management. Even though employee participation in management is nothing new, nevertheless its importance has increased and has been brought into sharp focus with the industrial revolution and the advent of large enterprises.

PDM is a basic element of a reasonable decision-making process. Decision-making may also refer to a process representing one's awareness to solve a problem by collecting alternatives and selecting one, which is perceived the best (Rice and Schneider, 1994). Conway (1980) mentioned eleven elements of PDM, those are participation in appointment of new staff, preparation of school or department budgets, textbook selection for department or school, resolutions of pupil academic or personal problems, construction of individual teaching timetables, resolutions of staff grievances, adoption of new teaching methods, decisions about new building facilities, resolutions of problems involving community groups (as parent or citizen groups), resolution of problems with administrative services (as clerks, typists, etc.), or decision concerning general teaching policy.

PDM comprises of participation from teachers in critical decision-making that directly affect their works. It involves some related issues such as school budgets, teacher hiring, class scheduling, and school curriculum (Bogler and Somech, 2004). In order to be effective, participation should be genuine from teachers. Teachers should be confident and believed that they have the knowledge and skills to make a situation better.

Dealing with participation indicators in education, Rice and Schneider (1994) indicated two main issues representing teacher involvement in decision-making; instruction/technical domain issues and school wide or managerial domain issues. In more detail, Mark and Louis (1997) proposed four domains of the PDM that are school management and operations, stu- dents' experiences, teachers' work life, and classroom management and classroom instruction.

Forms of PDM in many countries are affected by several factors such as historical aspects, cultural and economic conditions and political agendas. Studies relating to PDM in schools have been conducting in many different places nonetheless, questions regarding its implementation in non-western countries still persist waiting evidences. Because of its importance, employee PDM has been commonly practiced in many organizations in Australia. Participation is believed to help promote work effort, job satisfaction and employee commitment (Ladd et al., 2006). Participation has become a well-known concept and widely practiced in China. Workers are requested to participate in the top level decisions and managers also participate in daily activities at the lower level (Zhong-Ming, 1994). This practice has been successfully promoting organizational effectiveness, technical innovation and employee motivation in China.

Ladd et al. (2006) cited that involving employee in decision-making can increase employee satisfaction and employee commitment. In turn, with PDM, uncertainty, task ambiguity and role conflict can be reduced and teamwork in the organization can be promoted. It had also been confirmed by several studies finding that PDM becomes a significant predictor of job commitment (Bogler and Somech, 2004). Several researchers have also revealed that PDM has a significant influence on employee satisfaction and performance (Parnell and Crandall, 2003).

Participation has not only an important role in business or industrial sector and in education sector but also becomes one of the prominent factors affecting performance (Lipman, 1997; Clinton and Hunton, 2001). In business sector, it was found that PDM appears to promote employee commitment and job satisfaction (Ladd et al., 2006; Pereira and Osburn, 2007). Black and Gregersen (1997) gave an additional evidence by proving that employee's participation in managerial functions signifi- 
cantly influence employee satisfaction and employee performance.

Mualuko, et.al. (2009) confirmed that by involving lecturers in decision-making, the quality of decisions and their morale in their performance of duty will be higher. In an effort to identify the determinants of employee's participation in decision making, Neubert and Cady (2001) found that organizational commitment has a significant and positive relationship with participation as measured by Pearson correlation $(\mathrm{r}=0.17 ; \mathrm{p}<0.01)$. Participative management causes employees to learn to identify themselves with their job and it can increase employee performance. Furthermore, involving employees in decision making can increase employee motivation. PDM makes employees feel more accepted and involved in the organization (Aswathappa, 2002). Therefore, PDM in education is perceived as an important factor influencing school effectiveness (Bogler and Somech, 2004).

Scholars note that teachers' participation can improve their commitment, expertise, and teaching effectiveness (Marks and Louis, 1997). On the basis of individual differences perspective, participation has not only an important role in business or industrial sector and in education sector but also becomes one of the prominent factors affecting performance (Lipman, 1997; Clinton and Hunton, 2001).

Therefore this research is mainly addressed to ebserve participative decision making in higer education institutions (HEIs) in Indonesia. Examining lecturer participation in Indonesian higher education will not only facilitate education policy makers with a very useful input for their next better decision making in accelerating higher education institutions (HEIs) performances, but also provide a new horizon relating to research methodology in human resource management research. Based on the foregoing literature reviews, the following arethe research hypotheses proposed.

H1: The more lecturer participates in decisionmaking, the higher his/her satisfaction will be towards his or her organization.
$\mathrm{H} 2$ : The more lecturer participates in decisionmaking, the higher level he/she will commit to his/her organization.

H3: The more lecturer participates in decisionmaking, the higher his/her performance will be for the organization.

\section{METHODS}

A total of 61 packets of questionnaires were collected to the accounting lecturers at faculty of economics and business among universities in Yogyakarta Special Region during January until March 2010. This study elaborated an open ended questionnaire with fivepoint likert scale. Theoretically, there are much debate on what constitutes the best number of rating levels. The reliability of ratings drops if there are fewer than three or more rating categories while there is little gain from having more than five response categories.Based on this theoretical reasoning, this study usedselfrating instruments with five-point Likert scale to measure participative decision making and other related variables. To minimize bias existence resulting from subjectivity and carelessness in responding to the question, dualrater approachwas employed. Besides, documentation also backuped the questionnaires in completing related data. In this study, research instrument was rated by lectures themselves and their peers.

Instruments employed in this study were comprised of four components. First, observing level of lecturer participation was designed by requestingpeopleto perceive their PDM related to instruction/technical level and school wide or managerial level was the way one might do to measure lecturer participation in education studies (Conway, 1980; Rice and Schneider, 1994; Marks and Louis, 1997). An instrument developed by Marks and Louis (1997) was adopted in this research. It was considered as the most complete instrument in assessing PDM compared to others.

Second, an instrument for measuring lecturer performance developed by Finelli et al. (2008) was choosed to be used in this study. It has fifteen items representing an ideal teaching 
performance. Third, an insturment to measure job satisfaction developed by Rice and Schneider (1994) had been used.It was amore specific but comprehensive instrument to measure job satisfaction in education study having nine indicators. Complete nine indicators of lecturer's satisfaction used in this research were "administration/supervision, co-workers, future career, school identification, financial aspects, work conditions, amount of work, student-lecturer relations, and community relations". Finally, this research adoptedan eighteen-item of organizational commitment instrument, which was developed by Smeenk, et al. (2008). It was originaly from Allen and Meyer (1990). It has three main dimensions namely, affective, continuance, and normative dimensions.

Four conclusions were drawn based on the factor and reliability analysis. Firstly, an instrument measuring lecturer's participation in decision making with 12 items developed by Marks and Louis (1997) was adopted. It was found that all participation items loaded accordingly in the same factor with loading value greater than 0.50 (Hair et al., 2006) and latent roots (eigen value) equal to 4.834 greater than 1 as it is required (Wise, 1998). Besides, 9.121\% variance of all latent variables was explained by lecturer participation variable. Cronbach's Alpha coefficient shownfor both raters was greater than 0.800 indicated that the instrument used to measure lecturer participation was reliable (Hair et al., 2006).

Secondly, nine items with five point scales were administered and distributed to the lecturers to measure lecturer satisfaction. Rice and Schneider's lecturer satisfaction (1994) was adopted to assess lecturer's satisfaction.Based on statistical figures listed in Table 3.12, loading value of all indicators of lecturer satisfaction span from 0.518 to 0.788 loaded in one factor indicated that the instrument was unidimensional and valid (Wise, 1998; Hair et al., 2006). About $5.458 \%$ of variance could be explained by lecturer satisfaction. Total of eigen value was 4.315 greater than 1 and Cronbach's Alpha coefficient for both raters was- greater than 0.800again could indicate that the instrument was qualified (Hair et al., 2006).

Thirdly, to measure level of lecturer commitment in educational institution, an instrument developed by Smeenk et al. (2008) was adopted in this research. Based on the result of factor analysis presented in Table 3.12, it indicates that from 18 items administered to measure lecturer commitment, 8 items did not perform well that were indicated by loading values less than 0.50 . For the next analysis those 8 items were excluded. Factors that can affect the problem were respondents' fatigue and laziness. Subjective fatigue increased with increasing time-on-task (Ackerman and Ruth, 2009). By entering the remaining10 items, eigen value was 9.731 higher than it was required (Wise, 1998) and Cronbach's Alpha coefficient was 0.800 for both raters that can be infered that the instrument used to measure lecturer commitment was reliable (Hair et al., 2006).

Finally, on the basis of exploratory factor analysis, lecturer performanceinstrument performed very well in assessing lecturer performance. It was indicated by all six items loaded at more than 0.50 nesting in one factor. Composite variable was able to explain $5.114 \%$ variance. All indicators indicate lecturer performance very well. The loadings range from 0.613 (the lowest) to 0.804 (the highest). Cronbach's Alpha coefficient for both raters was greater than 0.800 again could indicate that the instrument for measuring performance was also qualified (Hair et al., 2006).Tabulation approach employed to describe demographic data and descriptive data of variables.Anova and linear regression analysis were also conducted to test demographic data on each variable and three hyphoteses.

Table 1 depicts demographic condition of respondents. Twenty seventh males and thirty four females from public and private universities were participated in this reseach. From those, more than $50 \%$, have dedicated in teaching for more than 12 years and older than 40 years old. Based on the age and experience, it 
is said that sample selected was representative enough but the number was still less.

As shown in Table 2, mean value of respondents' perception on PDM, lecturer satisfaction, lecturer commitment, and lecturer performance span from around 2.957 (moderate level) to 3.993 (high level). Lecturers perceivetheir own participation in decision making is in the moderate level (2.957). Conversely, peer's perception of lecturers PDM is high level (3.241). This phenomenon may be affected bya high power distance of Indonesian culture that it tends to push people respect other higher. Nevertheless, both lecturer and peer perception on satisfaction, performance and commitment are quite similar.

Further exploration employement status and sex on participation it is found that whether the status of employement is public or private and the gender type is male or female, there is significantly no different on the level of participation in decision making among accounting lecturers in faculty of economics and business.

\section{Research Finding and Discussion}

Table 1. Demographic Data

\begin{tabular}{|c|c|c|c|}
\hline \multicolumn{2}{|c|}{ Description } & \multicolumn{2}{|c|}{ Type of University } \\
\hline & & Public & Private \\
\hline \multirow[t]{2}{*}{ Lecturer's Sex } & Male & 5 & 22 \\
\hline & Female & 8 & 26 \\
\hline \multirow[t]{2}{*}{ Employement Status } & Public & 13 & 13 \\
\hline & Private & 0 & 35 \\
\hline \multirow[t]{6}{*}{ Experience } & Less than 4 years & 1 & 5 \\
\hline & 4 - less than 8 years & 5 & 8 \\
\hline & 8 - less than 12 years & 1 & 7 \\
\hline & 12 - less than 16 years & 2 & 9 \\
\hline & 16 - less than 20 years & 1 & 8 \\
\hline & 20 years or more & 3 & 11 \\
\hline \multirow[t]{6}{*}{ Age } & Under 25 years of age & 0 & 0 \\
\hline & 25 - less than 33 years & 5 & 6 \\
\hline & 33 - less than 41 years & 3 & 13 \\
\hline & 41 - less than 49 years & 2 & 19 \\
\hline & 49 - less than 57 years & 2 & 9 \\
\hline & 57 years or above & 1 & 1 \\
\hline
\end{tabular}

Table 2. Descriptive Statistics of Lecturer Participation, Lecturer Satisfaction, Lecturer Commitment and Lecturer Performance

\begin{tabular}{lccccc}
\hline \multicolumn{1}{c}{ Variable } & $\mathbf{N}$ & Min & Max & Mean & SD \\
\hline LECPAR & 61 & 1.500 & 4.580 & 2.957 & 0.819 \\
LECSAT & 61 & 2.110 & 5.000 & 3.533 & 0.656 \\
LECCOM & 61 & 1.700 & 5.000 & 3.993 & 0.667 \\
LECPER & 61 & 1.500 & 4.830 & 3.420 & 0.717 \\
PEERPAR & 61 & 1.360 & 4.820 & 3.241 & 1.029 \\
PEERSAT & 61 & 2.220 & 4.560 & 3.457 & 0.592 \\
PEERCOM & 61 & 2.180 & 5.000 & 3.674 & 0.732 \\
PEERPER & 61 & 1.500 & 5.000 & 3.713 & 0.815 \\
\hline
\end{tabular}


Table 3. Independent Samples Test

\begin{tabular}{|c|c|c|c|c|c|c|c|}
\hline \multicolumn{8}{|c|}{ Based on Employment Status (Public or Private) } \\
\hline \multirow{2}{*}{ Variable } & $\begin{array}{r}\text { Levene's } \\
\text { Equa } \\
\text { Vari }\end{array}$ & $\begin{array}{l}\text { st for } \\
\text { of } \\
\text { es }\end{array}$ & \multicolumn{5}{|c|}{ t-test for Equality of Means } \\
\hline & $\mathrm{F}$ & Sig. & $\mathrm{t}$ & df & $\begin{array}{l}\text { Sig. }(2- \\
\text { tailed })\end{array}$ & $\begin{array}{c}\text { Mean } \\
\text { Difference }\end{array}$ & $\begin{array}{l}\text { Std. Error } \\
\text { Difference }\end{array}$ \\
\hline $\begin{array}{l}\text { Lecturer } \\
\text { Participation }\end{array}$ & ,366 &, 548 &,- 833 & 59 & ,408 &,- 17709 & ,21269 \\
\hline Lecturer Satisfaction & 1,623 & ,208 & $-1,096$ & 59 & ,278 &,- 1856484 & , 1694380 \\
\hline $\begin{array}{l}\text { Lecturer } \\
\text { Commitment }\end{array}$ & ,012 & ,915 &,- 222 & 59 &, 825 &,- 0308022 & , 1385775 \\
\hline $\begin{array}{l}\text { Lecturer } \\
\text { Performance }\end{array}$ & ,023 & ,880 & $-1,944$ & 59 & 057 &,- 35278 &, 18149 \\
\hline \multicolumn{8}{|c|}{ Based on Sex (Male and Female) } \\
\hline $\begin{array}{l}\text { Lecturer } \\
\text { Participation }\end{array}$ & ,037 & ,849 & 1,207 & 59 & ,232 & ,25389 & ,21042 \\
\hline Lecturer Satisfaction & 1,015 & ,318 &,- 333 & 59 & ,740 &,- 0566776 & , 1702459 \\
\hline $\begin{array}{l}\text { Lecturer } \\
\text { Commitment }\end{array}$ & ,285 &, 595 & ,394 & 59 & 695 & ,0542919 & , 1378490 \\
\hline $\begin{array}{l}\text { Lecturer } \\
\text { Performance }\end{array}$ &, 155 & ,696 &,- 602 & 59 &, 550 &,- 11185 &, 18582 \\
\hline
\end{tabular}

Further exploration of demographic data on the variables, it was found no impact of both age and experience on lecturer participation, satisfaction, and commitment, but experience significantly differentiate lecturer with less from longer experience. Longer experience may be interpreted that lecturer has also more in managing classes, conducting research and publications, and committing to serve community. Consequently, they would be better managing academic activities and in handling problems arising at work.

Table 5 indicates that lecturer were least involved in setting school building and budget but much high involved in selecting teaching strategies. Other related less lecturer participation are indicated on determining the content of practical subjects, setting policy on class size, determining student behavior codes and teaching schedule. In general lecturer participation in decision making process among accounting lecturers at faculty of economics and business in Yogyakarta is still in moderate level (2.957).
Beginning this section, the comparison of hypotheses testing results between raters is presented in Table 6below and the discussion follows.

Based on the regression coefficients presented in Table 6, both lecturer and peer perception based, no effect of participation on decision making on lecturer commitment, satisfaction, nor on performance, unless on the basis of lecturer perception, participation on decision making significantly affects on lecturer performance $(\beta=0.300, \alpha=0.007)$. The such anomaly may be affected by unclear objectives, lack of group committment to escort and realize the decision made, lack of physical facilities and support procedures. Although participative decision making was run, if the leader still centralizes more dominant in making any final decision, then the lecturer satisfaction, commitment, and performance will never get better. Regarding positive impact of participation on lecturer performance, this finding implies intervening, moderating, or exogenoues variables are playing the role behind the phenomena. 
Table 4. Anova Test on Age and Experience

\begin{tabular}{|c|c|c|c|c|c|c|}
\hline & & $\begin{array}{l}\text { Sum of } \\
\text { Squares }\end{array}$ & df & $\begin{array}{l}\text { Mean } \\
\text { Square }\end{array}$ & $\mathrm{F}$ & Sig. \\
\hline \multicolumn{7}{|c|}{ Based on Age } \\
\hline \multirow[t]{3}{*}{ Lecturer Participation } & Between Groups & 1.667 & 4 & 0.417 & 0.604 & 0.661 \\
\hline & Within Groups & 38.617 & 56 & 0.690 & & \\
\hline & Total & 40.284 & 60 & & & \\
\hline \multirow[t]{3}{*}{ Lecturer Satisfaction } & Between Groups & 2.044 & 4 & 0.511 & 1.205 & 0.319 \\
\hline & Within Groups & 23.739 & 56 & 0.424 & & \\
\hline & Total & 25.783 & 60 & & & \\
\hline \multirow[t]{3}{*}{ Lecturer Commitment } & Between Groups & 1.235 & 4 & 0.309 & 1.102 & 0.365 \\
\hline & Within Groups & 15.682 & 56 & 0.280 & & \\
\hline & Total & 16.917 & 60 & & & \\
\hline \multirow[t]{3}{*}{ Lecturer Performance } & Between Groups & 1.482 & 4 & 0.371 & 0.707 & 0.591 \\
\hline & Within Groups & 29.366 & 56 & 0.524 & & \\
\hline & Total & 30.848 & 60 & & & \\
\hline \multicolumn{7}{|c|}{ Based on Experience } \\
\hline \multirow[t]{3}{*}{ Lecturer Participation } & Between Groups & 1.349 & 5 & 0.270 & 0.381 & 0.860 \\
\hline & Within Groups & 38.936 & 55 & 0.708 & & \\
\hline & Total & 40.284 & 60 & & & \\
\hline \multirow[t]{3}{*}{ Lecturer Satisfaction } & Between Groups & 2.792 & 5 & 0.558 & 1.336 & 0.263 \\
\hline & Within Groups & 22.991 & 55 & 0.418 & & \\
\hline & Total & 25.783 & 60 & & & \\
\hline \multirow[t]{3}{*}{ Lecturer Commitment } & Between Groups & 2.222 & 5 & 0.444 & 1.663 & 0.159 \\
\hline & Within Groups & 14.695 & 55 & 0.267 & & \\
\hline & Total & 16.917 & 60 & & & \\
\hline \multirow[t]{3}{*}{ Lecturer Performance } & Between Groups & 6.251 & 5 & 1.250 & 2.796 & 0.025 \\
\hline & Within Groups & 24.597 & 55 & 0.447 & & \\
\hline & Total & 30.848 & 60 & & & \\
\hline
\end{tabular}

\section{Table 5. Lecturer Participation Indications}

\begin{tabular}{llcccc}
\hline \multicolumn{1}{c}{ Description } & N & Min & Max & Mean & SD \\
\hline 1. Planning the school building and budget & 61 & 1 & 5 & $\mathbf{1 . 9 6 7}$ & 1.341 \\
2. Determining the teaching schedule & 61 & 1 & 5 & 2.672 & 1.434 \\
3. Determining teaching or other professional assignments & 61 & 1 & 5 & 3.000 & 1.414 \\
4. Establishing the curriculum & 61 & 1 & 5 & 3.197 & 1.352 \\
5. Selecting new employees & 61 & 1 & 5 & 3.049 & 1.203 \\
6. Determining the content of practical subjects & 61 & 1 & 5 & 2.131 & 1.258 \\
7. Determining student behavior codes & 61 & 1 & 5 & 2.672 & 1.434 \\
8. Disciplining students & 61 & 1 & 5 & 3.377 & 1.186 \\
9. Setting policy on a class size & 61 & 1 & 5 & 2.246 & 1.274 \\
10. Selecting textbooks and other instructional materials & 61 & 1 & 5 & 3.689 & 1.073 \\
11. Selecting content. topics and skills to be taught & 61 & 1 & 5 & 3.721 & 1.051 \\
12. Selecting teaching strategies & 61 & 1 & 5 & $\mathbf{3 . 7 7 0}$ & 1.101 \\
$\quad$ Lecturer Participation (Agregate) & 61 & 1.500 & 4.580 & $\mathbf{2 . 9 5 7}$ & 0.819 \\
\hline
\end{tabular}


Table 6. Coefficients of Regression

\begin{tabular}{lclccc}
\hline \multicolumn{1}{c}{ Independent Variables } & Direction & $\begin{array}{c}\text { Dependent } \\
\text { Variables }\end{array}$ & Estimate & S.E. & Sig. \\
\hline LECTURER RATING & & & & & \\
LECPAR & $--->$ & LECSAT & 0.156 & 0.102 & 0.133 \\
LECPAR & $--->$ & LECCOM & 0.173 & 0.103 & 0.101 \\
LECPAR & $-->$ & LECPER & 0.300 & 0.107 & $\mathbf{0 . 0 0 7}$ \\
\hline PEER RATING & & & & & \\
\hline PEERPAR & $--->$ & PEERSAT & 0.105 & 0.074 & 0.160 \\
PEERPAR & $--->$ & PEERCOM & 0.150 & 0.091 & 0.104 \\
PEERPAR & $-->$ & PEERPER & 0.098 & 0.102 & 0.344 \\
\hline
\end{tabular}

Table 7. Summary of the Hypotheses Testing Results

\begin{tabular}{lllc}
\hline \multirow{2}{*}{ No } & \multicolumn{1}{c}{ Hypotheses } & \multicolumn{2}{c}{ Testing Results } \\
\cline { 3 - 4 } & & Lecturer Rating & Peer Rating \\
\hline 1. & $\begin{array}{l}\text { The more lecturer participates in decision-making, the higher } \\
\text { his/her satisfaction will be towards his or her organization. }\end{array}$ & Rejected & Rejected \\
2. $\quad \begin{array}{l}\text { The more lecturer participates in decision-making, the higher } \\
\text { level he/she will commit to his/her organization. } \\
\text { The more lecturer participates in decision-making, the higher } \\
\text { his/her performance will be for the organization. }\end{array}$ & Accepted & Rejected \\
\end{tabular}

Zhong-Ming (1994) argues that PDM is very important element in an efficient decision making. It may be used to solve conflict of interests among individuals or groups of people in an organization (Alipour et al., 2009). Besides, PDM can be used to communicate organizational objectives (Zhong-Ming, 1994). Employees who participate in decision making will have higher satisfaction compared to those who do not participate (Boglerand Somech, 2004). PDM balances managers' and administrators' involvement and subordinates' participation in processing information and solving organizational problems.

This research findings failto confirmed that PDM can improve lecturer satisfaction in HEIs in Indonesia. The failure may caused by conditions of PDM will be successful to be implemented were not existed in the such local area (higher education institutions in Yogyakarta Province). This finding is contradictory to the previous finding from Bhatti and Qureshi (2007). Furthermore, it is also in contrast to the research findings from Bhatti and Qureshi (2007). They found that employees who participate more in decision making feel more satisfied, show more loyalty to their organization and increase their productivity.

PDM benefits organizations with improvement of their quality of decisions and faciletates organizational communication (ZhongMing, 1994). Generally, people who involve more in a project will have a higher participation in decision making (Neubert and Cady, 2001). There are three approaches due to how PDM works in organizations (Pereira and Osburn, 2007). First, the cognitive approach states that it affects more on job productivity than on job satisfaction. Secondly, the affective model states that it will fulfill people's higher-level needs, which in turn will affect job satisfaction and job productivity. In this second model, the effect of PDM on job satisfaction will be stronger than the effect of PDM on job productivity. Thirdly, the contingency model predicts 
that different outputs for PDM depend on the work situation.

Scott et al. (2003) suggested an environment in order that PDM increases employee satisfaction: (1) there is a willingness from employees to accept suggestions from others about their work; (2) PDM should improve employee commitment and feelings of ownership; (3) personal inputs from others improve employee positive feelings about their job; (4) people feel they have a responsibility to their work; (5) people enjoy the chance to interact with others during their tenure; and (6) the more lecturer participates in decision-making, the higher level he/she will commit to his/her organization.

Ladd et al. (2006) and Bhatti and Qureshi (2007) stated that participation promote lecturerloyalty to an organization. In turn, lecturer commitment will reduce uncertainty, ambiguity and role conflict and promote teamwork. Finding fails to support hypothesis. It contradicts with an assumption proposed by Marks and Louis (1997) stating that teacher participation in decision making can enhance teacher's commitment. It also supports several studies in which PDM has become a significant predictor of job commitment (Neubert and Cady, 2001; Bogler and Somech, 2004).

Participation in school decision making can enhance teachers' commitment, expertise, and effectiveness (Marks and Louis, 1997). Lipman (1997) writes that teacher participation is to reenergize schools, unleash teachers' initiative and creativity, and get them to buy in to the restructuring agenda.Participation may also enhance teacher's sense of responsibilities, shared culture, and teacher commitment (Lipman, 1997: 4).

Nevertheless, based on the lecturer perception, the findings of this research fail to provide empirical support regarding the relationship between lecturer participation and commitment as it has been indicated by previous researchers (Gaertner, 1999; Wang, 2007). The contradiction happens because there is a different perception between lecturer and peer in rating PDM and organizational commitment.
Even though PDM benefits organizations, managers sometimes resist it. Managers perceive that PDM can undermine their autonomy and control on people in an organization. PDM often is perceived to threaten job security and make substantial changes in their management styles (Parnell and Crandall, 2001). That is why, PDM results benefits to the organization if it is conducted properly. If not, it will waste time to reach an agreement. Kessler (1993) identified seven pitfalls in the implementation of PDM: (1) trying to reach an agreement through discussion if the group members are less than four people; (2) trying to discuss issues in a limited time; (3) involving people who do not have relationship with the output of the decision-making process; (4) involving people who do not understand the issues being discussed; (5) involving people at wrong level in the decision-making process; (6) inviting too many people in making decisions; and (7) proposing too many consensuses in the decisionmaking process.

As it is described in the literature review, PDM has an important role in promoting employee performance, and job satisfaction. Although it is debatable since raters' data have different patterns, the research found that lecturer involvement in decision making process improves lecturer performance in HEIs in Indonesia. It suggests that providing lecturers a space to participate in decision-making process can improve not only lecturer commitment, expertise, and effectiveness, responsibilities and shared culture but also lecturer performance.

\section{CONCLUSION}

Based on the data analysis, several conclusions can be drawn. Firstly, involving lecturer in decision making cannot significantly increase lecturer satisfaction. This research failed to provide empirical support regarding the relationship between lecturer participation and commitment as suggested by previous researchers. In contrast, based on lecturerrating, this research's result confirms that PDM has a positive and significant effect on lecturer performance. To promote the functions of PDM, it is 
suggested organizations to increasetheir employees'knowledge and skills.

In line with the research findings, several possible implications could be indicated.Shared decision-making can improve the quality of decisions and promote cooperation if the right strategy is linked to the right situation. It is widely believed that involving employees in decision making process will promote employee satisfaction, employee loyalty and productivity and also creates comparative advantage for the organization (Bhatti and Qureshi, 2007). This research is successfulin providing evidence that PDM had a significant impact on lecturer performance, but it has failed to confirm the relationship between PDM and lecturer satisfaction and lecturer commitment.

Itis indicated that lecturers do not always commit to the aims of the university that is resulted fromthe existence of difference of their personal agendas from the school's goals. Resistance to the change from both lecturers and leaders is the biggest drawback in PDM. Besides, lecturers might consider PDM to be just empty rhetoric when advocating or implementing without any proper compensation. Another problem is that administrators just attempt to exploit lecturers with PDM.

It is very important to describe the limitations of the present research. Subsequently, two concerns were identified in which they might decrease the power of generalizability of the research findings. Firstly, all measurements consist only of self-assessment items which ask respondents to provide ratings of lecturer performance and its determinants. Over or underestimates were more likely to be found if the self-assessments are employed in a survey. Young people may over-estimate because they lack the cognitive skills to integrate information about their abilities and were more vulnerable to wishful thinking (Roos, 2006). Self-assessment might also possess bias against a particular sex, social class, nationality, or racial group (Aiken, 1999). To examine influence of the bias issues, more studies are still needed.

Secondly, by using Slovin method, the sample size should be at least 385 people of each group (Umar, 2006; Visco, 2006). A total of 750 questionnaires were distributed to each group of rater in 39 different universities in Yogyakarta Province, nevertheless the response rate was lower than expected, so the generalizability of this research findings might not be appropriate beyond the respondents retained in the study (Currivan, 1999).

It is strongly recommended for educational leaders to encourage a higher level of lecturers' involvement in decision making process. By doing so, this policy is expected toincrease lecturer's performance and university's performance. To address the research limitations and to conduct more reliable and rigorous research, several recommendations were proposed. First, in addition to self-rating it was suggested to use data triangulation by gathering data through different time frames (longitudinal study), different places (different provinces or islands), different format (secondary data), or involving a variety of raters (supervisor or head of department).

Second, to increase the generalizabilityof the research findings, sample size and response rate should be increased. Smith (2007) suggested five strategies to increase response rate: (1) develop clear instructions, purpose and questions; (2) motivate the respondents to respond; (3) make respondents interested to the survey; (4) provide reasonable time and ease of completing the survey. Finally, provide incentives and rewards for completion.

Lastly, another suggestion is related to the variable being investigated. To provide more complete picture of factors affecting lecturer performance, it is recommended to consider other variables such as ability, motivation, effort, selection practices, training and development, employee relations and organization strategy (Noe et. al., 2007) and organizational culture, organizational structure, job stress and leadership style (Rose et al., 2008).

\section{ACKNOWLEDGEMENTS}

I would like to extend my appreciation to the Editorial Board of Cakrawala Pendidikan, especially Prof. Dr. Burhan Nurgiantoro for the 
inclusion of this article in the current publication. My thanks also go to the Editorial Staff for their patience and prompt service so that this article can be published in the present edition.

\section{REFERENCES}

Ackerman, P.L. and Ruth, K. 2009. "Test Length and Cognitive Fatigue: An Empirical Examination of Effects on Performance and Test-Taker Reactions", in Journal of Experimental Applied Psychology, 15(2), 163-181.

Aiken, L.R. 1999. Personality Assessment, Methods and Practices. ( ${ }^{r d}$ ed.). Seatle Toronto: Hogrefe \& Huber Publisher.

Alipour,M., Salehi, M. and Yahyavi, M. 2009. "An Empirical Study of Participative Management Role in Employees Effectiveness: Case of Islamic Azad University in Iran", in Interdiciplinary Journal of Contemporary Research in Business, 1(8), 148-167.

Allen, N. J. and Meyer, J. P. 1990. "The Measurement and Antecedents of Affective, Continuance and Normative Commitment to the Organization", in Journal of Occupational Psychology, 63(1), 1-18.

Aswathappa, K. 2002. Human resource and Personnel Management:Text and Cases. $\left(3^{\text {rd }}\right.$ ed.). New Delhi: Tata McGraw-Hill Incorporation.

Bhatti, K.K. and Qureshi, T.M. 2007. "Impact of Employee Participation on Job Satisfaction, Employee Commitment and Employee Productivity", in International Review of Business Research Papers, 3(2), 54-68.

Black, J.S. and Gregersen, H. B. 1997. Participative Decision-Making: An Integration of Multiple Dimensions. Human Relations, 50(7), 859-878.

Bogler, R. and Somech, A. 2004. "Influence of Teacher Empowerment on Teachers' Organizational Commitment, Professional Commitment and Organizational Citizen- ship Behavior in Schools". in Teaching and Teacher Education, 20(3), 277-289.

Brodjonegoro, S.S. 1997. Some thoughts on Quality Improvement and Competitiveness of Higher Education Institutions in Indonesia, Working Paper of the Academic Leaders of the State and Private Higher Education Institutions Conference, Jakarta.

Clinton, B.D. \& Hunton, J.E. 2001. "Linking Participative Budgeting Congruence to Organization Performance", in Behavioral Research In Accounting, 13, 127 141.

Conway, James A. 1980. Power and Participatory Decision Making in selected English Schools: Approach to School Management. London: Harper and Row $\mathrm{Pu}-$ blishers.

Creech, J.D. 2000. Linking Higher Education Performance Indicators to Goals: Educational Benchmarks 2000 Series. Atlanta: Southern Regional Education Board.

Del-Val, M.P. and Lloyd, B. 2003. "Measuring Empowerment", in Leadership \& Organization Development Journal, (pp. 102 103).

Finelli, C.J., Ott, M., Gottfried, AC., Hershock, C., O'Neal, C. and Kaplan, M. 2008. "Utilizing Instructional Consultations to Enhance the Teaching Performance of Engineering Faculty", in Journal of Engineering Education, 97(4), 397-411.

Gaertner, S. 1999. "Structural Determinant of Job Satisfaction and Organizational Comitment in Turnover Models", in Human Resource Management Review, 9(4), 479-493.

Hair, J.F., William C.B, Barry J.B, Rolph E.A. and Ronald L.T. 2006. Multivariate Data Analysis. Singapore: Pearson Prentice Hall Incorporation.

Ikhsan, J. and Asih, A.A. 2008. Exploring the ideas of Creating Higher Education Common Space in Indonesia, Paper Presented in The International Conference Se- 
ries on Raising Awareness: Exploring the Ideas of Creating Higher Education Common Space in Southeast Asia. Bangkok. Retreived 12 August 2010 from http://www.rihed.seameo.org/harmonise2 008 /har_indo.pdf.

Kessler, F.A. 1993. "How to Avoid Common Pitfalls of Consensus Decision Making", in Oil \& Gas Journal, 91(39), 34-36.

Ladd, B.S., Travaglione, A. and Marshall, V. 2006. Causal Inferences between Participation in Decision Making, Task Attributes, Work Effort, Rewards, Job Satisfaction and Commitment. Leadership \& Organization Development Journal, 27 (5), 399-414.

Lipman, P. 1997. "Restructuring in Context: A Case Study of Teacher Participation and the Dynamics of Ideology, Race and Power", in American Education Research Journal, 34(1), 3-37.

Marks, H.M. and Karen, S. Louis. 1997. "Does Empowerment Affect the Classroom? The Implication of Teacher Empowerment for Instructional Practice and Student Academic Performance", in Educational Evaluation and Policy Analysis, 19(3), 245-275.

Mualuko, N.J., Mukasa, S.A. and Judy, A.S.K. 2009. Improving Decision Making in Schools through Teacher Participation. Educational Research and Review, 4(8), 391-397.

Neubert, M.J. and Cady, S.H. 2001. "Program commitment: A Multi-Study Longitudinal Field Investigation of Its Impact and Antecedents", in Personnel Psychology, 54(2), 421-447.

Noe, R.A., Hollenbeck, J.R., Herhart, B. And Wright, P.M. 2007. Foundamental of Human Resource Management. ( $2^{\text {nd }}$ ed.). Boston: McGrawHill Companies Incorporation.

Parnell, J.A.and Crandall, W.R. 2003. "Propensity for Participative Decision-Making, Job Satisfaction, Organizational Commitment, Organizational Citizenship Beha- vior, and Intentions to Leave among Egyptian Managers", in Multinational Business Review, 11(1), 45-65.

Pereira, G.M. and Osburn, H.G. 2007. "Effects of Participation in Decision-Making on Performance and Employee Attitudes: A Quality Circles Meta-Analysis", in Journal of Bussiness and Psychology, 22(1), 145-153.

Podgursky, M.J. and Springer, M.G. 2007. "Teacher Performance Pay: A Review", in Journal of Policy Analysis and Management, 26(4),909-949.

Porter, M. E. 2002. Building the Microeconomic Foundations of Prosperity: Findings from the Microeconomic Competitiveness Index. New York: Oxford University Press.

Rice, E.M., and Schneider, G.T. 1994. "A Decade of Teacher Empowerment: An Empirical Analysis of Teacher Involvement in Decision Making". Journal of Educational Administration, 32(1), 4359.

Rice, J.K. 2003. Teacher Quality: Understanding the Effectiveness of Teacher Attributes. Washington: Economic Policy Institute.

Rose, R.C., Kumar, N., Abdullah, H. and Ling, G.Y. 2008. Organizational Culture as a Root of Performance Improvement: Research and Recommendations. Contemporary Management Research, 4(1), 4356.

Ross, J.A. 2006. "The reliability, validity, and utility of self-assessment", in Practical Assessment, Research \& Evaluation, 11(10), 1-13.

Scott, D., Bishop, J.W. and Chen,X. 2003. "An Examination of the Relationship of Employee Involvement with Job, Employee Cooperation, and Intention to Quit in US Invested Enterprise in China", in Journal of Organizational Analysis, 11(1), 3-19.

Smeenk, S., Teelken, C., Eisinga, R., and Doorewaard, H. 2008. "An International Com- 
parison of the Effects of HRM Practices and Organizational Commitment on Quality of Job Performances among European University Employees", in Higher Education Policy, 21(3), 323-344.

Smith, S.M. 2007. How to Increase Online Survey Response Rates. Retreived 16 November 2010 from http://www.aboutsurveys.com/how-to-increase-online-survey-response-rates/.

Sulistiyono, S.T. 2007. Higher Education Reform in Indonesia at Crossroad. Paper Presented at the Graduate School of Education and Human Development, Nagoya University, Japan. Retreived 12 August 2010 from available at http://www.luk.staff.ugm.ac.id/atur/bhp /HEReform-Singgih.doc.

Umar, H. 2005. Riset Pemasaran dan Perilaku Konsumen. Jakarta: Gramedia Pustaka Utama.

Visco, E.S. 2006. "Dynamics of Conflict and Cooperation for Group Stability among Selected Government- Assisted Cooperatives in Region IV", in Philippines International Journal of Social Sciences, 1(4), 222-232.
Wang, X. 2007. "Learning, Job Satisfaction and Commitment: An Empirical Study of Organizations in China", in Chinese Management Studies, 1(3), 167-179.

Wicaksono, T.Y., and Friawan, D. 2008. Recent Development of Higher Education in Indonesia: Issues and Challenges. Paper Prepared for Discussion at the DPU East Asean Bureau of Economic Research EABER Conference on Financing Higher Education and Economic Development in East Asia, Bangkok. Retreived 7 January 2010 from http://www.eaber.org/intranet/ documents/80/WPS_DPU_2008_45.pdf.

Wise, P.G. 1998. Rating Differences in MultiRater Feedback: A New Look at an Old Issue. International Personnel Management Association Assessment Council's (IPMAAC) Conference on Professional Personnel Assessment, Chicago, Illinois. Retreived 8 October 2009 from http://www.ipacweb.org/conf/98/wise.pdf.

Zhong-Ming, W. 1994. "Organizational Decision Making and Competence Utilization Among Chinese Managers", in Journal of Managerial Psychology, 9(7), 17-25. 